\title{
THE EXISTENCE OF ENTOMOPATHOGENIC FUNGI ON RICE PLANTS RHIZOSPHERE
}

\author{
Noerfitryani* and Hamzah \\ Muhammadiyah Universiy Makassar, J1. Sultan Alauddin No. 259, Indonesia, 90221 \\ *Corresponding author: yhani.noerfitryani@gmail.com
}

\begin{abstract}
Enthomophatogenic fungi are one of bioinsecticides that can be used as pests control. This research aimed to identify and analyze the existence of fungi on semi-organic and inorganic rice plants rhizosphere and prove the role as entomophatogenic fungi. The research method isolation of fungi was conducted in Takalar Regency, semi-organic and inorganic rice plants rhizosphere and continued in Biological Laboratory, Plant Pests and Diseases Department, Faculty of Agriculture, Universitas Hasanuddin, Makassar. This research using a modified insect bait method, larvae mortality calculated, insect testing were infected in reisolation and fungal diversity index. The result showed that the average Tenebrio molitor larvae mortality infected of enthomopathogenic fungi on semi-organic rhizosphere was around $24 \%$ and $8 \%$ on inorganic rhizosphere. The percentage of larvae mortality on semi-organic rhizosphere were infected by Fusarium sp., range the percentage was around 20-60 \%, Aspergillus sp. 60\%-80\% and Trichoderma sp. 80\%, while in inorganic rhizosphere up to $100 \%$ were infected by Aspergillus spp.
\end{abstract}

Keywords: Semi-organic and inorganic, Rhizosphere, Entomopathogenic

\section{INTRODUCTION}

All microorganisms are present in rhizosphere, affect the growth of the plant, nutrient supply for plants, as biological control for pests. Enthomophatogenic fungi as biological agens are commonly found on rhizosphere. But the existence of microorganisms in the soil especially for this time has decreased. This is due to environmental pollution caused by agricultural activity continues that rely on chemical fertilizers (inorganic) and synthetic pesticides. Nutrients secretion into the rhizosphere of plants were influenced by environmental factors and further affect the abundance and diversity of microorganisms in the area (Kuswinanti et al, 2014).

There are about 700 types of entomopathogenic fungi, which is of 90 genera are represented (Goettel et al., 2010). Several types include Metharizium anisopliae (Priwiratama and Susanto, 2014), Beauveria bassiana (Malekan et al., 2015; Herlinda, 2010), Aspergillus (Bawin et al., 2016) Fusarium, Penicillium, Rhizopus, Trichoderma (Assaf et al., 2011).

Several studies of soil fungi were isolated from rhizosphere and potentially as biological control Trizelia et al., (2011) showed that, isolates Metarhizium spp. which 
is isolated from cabbage rhizosphere, virulent to eggs and larvae of Spodoptera litura instar I of larvae, and also Trizelia et al., (2015) showed that there were 3 genera of entomopathogenic fungi in various vegetable crops rhizosphere, Metharizium, Beauveria and Aspergillus with the highest diversity of entomopathogenic fungi were found in the tomato plant rhizosphere. Nurariaty et al., (2013) showed that mortality pupae and imago of cocoa pod borer infected enthomophatogenic fungi genera of Penicillium sp., Aspergillus sp. and Fusarium sp. Refer to Hamdani et al., (2011) there are 6 genus of entomopathogenic fungi were isolated from cocoa rhizosphere in different agroecosystems were Aspergillus, Metarhizium, Beauveria, Paecilomyces, Fusarium and Penicillium effective as controlling C.cramerella insects. However, no previous study has investigated the existence diversity of entomopathogenic fungi in semi organic and inorganic rice rhizosphere in South Sulawesi, therefore this study was conducted for determining control strategy in Integrated Pest Management (IPM) system.

\section{MATERIALS AND METHODS}

\section{Soil samples}

The present studies were conducted at Plant Pests and Diseases Department, Faculty of Agriculture, Universitas Hasanuddin, Makassar, during April- July. Soil samples were collected from semi-organic and inorganic rice ecosystem belonging to farmers in North Polongbangkeng SubDistrict Takalar Regency. Determined diagonally 5 points on the semi-organic and inorganic rice plants rhizosphere. Each point was taken in the rhizhosphere, at a depth 20$30 \mathrm{~cm}$ of soil with a volume of approximately $300 \mathrm{~g}$.

\section{Insect Bait Method}

The fungi were isolated by insect bait method (Zimmerman, 1986) modified. Larvae Tenebrio molitor as a test insect, each of 5 larvae were inserted into plastic cups (measuring $10 \mathrm{~cm} \mathrm{x} 16 \mathrm{~cm}$ ) containing $100 \mathrm{~g}$ of filter soil with a sieve 1100 mesh. Then covered with white cloth size $3 \mathrm{~cm} \times 3 \mathrm{~cm}$ and were incubated at $22-25{ }^{\circ} \mathrm{C}$. Larvae that were infected of fungi then placed in sterile filter paper were moistened. Larvae were infected of entomopathogenic fungi characterized by the appearance of mycelium of the fungus in each of the insect segment body. Surfaces sterilized using $70 \%$ alcohol for 1 minute and then rinsed with sterile distilled water, again kept in sterile distilled water and dry it on sterile filter paper, and then isolated larvae in fresh sterilized petri dish containing PDA and incubated for 3-7 days at $22-25{ }^{\circ} \mathrm{C}$. Thereafter, identified the fungi that grew on PDA. 
Bioassay Test of Entomopathogenic Fungi

The fungi that were identified then tested to determine their role as entomopathogen. The fungus was used in this experiment all the fungus obtained. The preparation suspension of spores for each fungus was obtained by the addition $10 \mathrm{ml}$ of

$\mathrm{t} x \mathrm{~d}$

$\mathrm{S}=$ X $10^{6}$

n $\times 0,25$

$\mathrm{S}=$ number of spores

$\mathrm{T}=$ total number of spores observed in square cell sample

$\mathrm{D}=$ dilution factor

$\mathrm{N}=$ number of square cell sample observed

$0.25=$ correction factor

application of suspense in a petri dish (diameter $20 \mathrm{~cm}$ ), placed 5 larvae of $T$. molitor as treatment. Next sprayed as much as $0.1 \mathrm{ml}$ of the suspension of the fungal spores were selected on test insect. Thereafter 24 hours carried out Larvae infected by fungi P $=$ number of larvae observed

\section{RESULTS AND DISCUSSION}

\section{Identification of Enthomophatogenic Fungi}

Identification of the fungi isolates were found based on macroscopic and microscopic morphology characteristics. The

sterile water into the petri dish containing the culture of the fungus for 8 days, then was homogenized by using spatula for 1 minute. Drop suspension on Haemocytometer then the number of spores counted by the formula 
Table 1. Cultural Characteristics of Various Isolates Fungi on PDA Isolated from Semi-organic Rhizosphere

\begin{tabular}{|c|c|c|c|c|c|c|c|c|}
\hline \multirow[b]{2}{*}{$\begin{array}{l}\text { Isolate } \\
\qquad \mathrm{s}\end{array}$} & \multicolumn{3}{|c|}{ Upper Surface } & \multirow{2}{*}{$\begin{array}{l}\text { Colon } \\
\text { y } \\
\text { Revers } \\
\text { e }\end{array}$} & \multirow[b]{2}{*}{$\begin{array}{l}\text { Conidia / } \\
\text { Spores }\end{array}$} & \multicolumn{2}{|c|}{ Hyphae } & \multirow[b]{2}{*}{ Genera } \\
\hline & $\begin{array}{l}\text { Color and } \\
\text { Cultural } \\
\text { aspect }\end{array}$ & $\begin{array}{c}\text { Densit } \\
\mathrm{y}\end{array}$ & Zonation & & & Color & $\begin{array}{l}\text { Setae / } \\
\text { None }\end{array}$ & \\
\hline $\begin{array}{c}\text { RSOT } \\
1\end{array}$ & $\begin{array}{l}\text { Light } \\
\text { greenish, } \\
\text { powdery, } \\
\text { white halo } \\
\text { (margin) and } \\
\text { cotton-like }\end{array}$ & High & $\begin{array}{l}\text { Concentr } \\
\text { ic zones }\end{array}$ & Cream & Globose & $\begin{array}{l}\text { Hyalin } \\
\mathrm{e}\end{array}$ & Setae & Aspergillus \\
\hline $\begin{array}{c}\text { RSOT } \\
2\end{array}$ & $\begin{array}{l}\text { Light green, } \\
\text { powdery, } \\
\text { white halo }\end{array}$ & High & $\begin{array}{l}\text { Concentr } \\
\text { ic zones }\end{array}$ & Cream & Globose & $\begin{array}{c}\text { Hyalin } \\
\mathrm{e}\end{array}$ & Setae & Apergillus \\
\hline \multirow{2}{*}{$\begin{array}{c}\text { RSOT } \\
3\end{array}$} & $\begin{array}{l}\text { White, cotton- } \\
\text { like }\end{array}$ & High & None & White & $\begin{array}{l}\text { Macroconid } \\
\text { ia slightly } \\
\text { curve, } \\
\text { microconidi } \\
\text { a bent }\end{array}$ & $\begin{array}{l}\text { Hyalin } \\
\mathrm{e}\end{array}$ & Setae & Fusarium \\
\hline & $\begin{array}{l}\text { White to dark } \\
\text { green, light } \\
\text { green halo, } \\
\text { cotton-like }\end{array}$ & High & $\begin{array}{l}\text { Concentr } \\
\text { ic zones }\end{array}$ & White & Ovoid & $\begin{array}{l}\text { Hyalin } \\
\text { e }\end{array}$ & Setae & $\begin{array}{c}\text { Trichoderm } \\
a\end{array}$ \\
\hline \multirow{2}{*}{$\begin{array}{c}\text { RSOT } \\
4\end{array}$} & $\begin{array}{l}\text { White to } \\
\text { creamish, } \\
\text { creamish halo, } \\
\text { cotton-like }\end{array}$ & High & $\begin{array}{l}\text { Concentr } \\
\text { ic zones }\end{array}$ & $\begin{array}{l}\text { Yello } \\
\text { w }\end{array}$ & $\begin{array}{l}\text { Macroconid } \\
\text { ia slightly } \\
\text { curve, } \\
\text { microconidi } \\
\text { a ovoid }\end{array}$ & $\begin{array}{l}\text { Hyalin } \\
\mathrm{e}\end{array}$ & Setae & Fusarium \\
\hline & $\begin{array}{l}\text { White to } \\
\text { creamish, } \\
\text { creamish halo, } \\
\text { cotton-like }\end{array}$ & High & $\begin{array}{l}\text { Concentr } \\
\text { ic zones }\end{array}$ & $\begin{array}{l}\text { Yello } \\
\text { w }\end{array}$ & $\begin{array}{l}\text { Macroconid } \\
\text { ia slightly } \\
\text { curve, } \\
\text { microconidi } \\
\text { a ovoid }\end{array}$ & $\begin{array}{l}\text { Hyalin } \\
\text { e }\end{array}$ & Setae & Fusarium \\
\hline
\end{tabular}

Note: Identification based on determination keys of the identification books (Barnett and Hunter, 1972; Watanabe, 2002). 
Table 2. Cultural Characteristics of Various Isolates Fungi on PDA Isolated from Inorganic Rhizosphere

\begin{tabular}{|c|c|c|c|c|c|c|c|c|}
\hline \multirow[b]{2}{*}{ Isolates } & \multicolumn{3}{|c|}{ Upper Surface } & \multirow[b]{2}{*}{$\begin{array}{l}\text { Colony } \\
\text { Reverse }\end{array}$} & \multirow[b]{2}{*}{$\begin{array}{c}\text { Conidia / } \\
\text { spores }\end{array}$} & \multicolumn{2}{|c|}{ Hyphae } & \multirow[b]{2}{*}{ Genus } \\
\hline & $\begin{array}{c}\text { Color and } \\
\text { Texture }\end{array}$ & Density & Zonation & & & Color & $\begin{array}{l}\text { Setae/ } \\
\text { None }\end{array}$ & \\
\hline \multirow{2}{*}{ RIOT1 } & $\begin{array}{l}\text { Black spores, } \\
\text { powdery, } \\
\text { white halo }\end{array}$ & High & $\begin{array}{c}\text { Single } \\
\text { concentric } \\
\text { zone }\end{array}$ & White & Globose & $\begin{array}{l}\text { Hyalin } \\
\mathrm{e}\end{array}$ & Setae & Aspergillus \\
\hline & $\begin{array}{l}\text { Light green, } \\
\text { powdery, } \\
\text { white halo }\end{array}$ & High & $\begin{array}{l}\text { Concentri } \\
\text { c zones }\end{array}$ & Cream & Globose & $\begin{array}{l}\text { Hyalin } \\
\text { e }\end{array}$ & Setae & Aspergillus \\
\hline
\end{tabular}

Note: Identification based on determination keys of the identification books (Barnett and Hunter, 1972; Watanabe, 2002).

Table 1 showed that 3 genera Aspergillus. The macroscopic and morphological identification were Fusarium, microscopic characteristics of the three types Trichoderma and Aspergillus, while on Table of fungi on (Figures 1-4).

2 showed that one genera, thas was
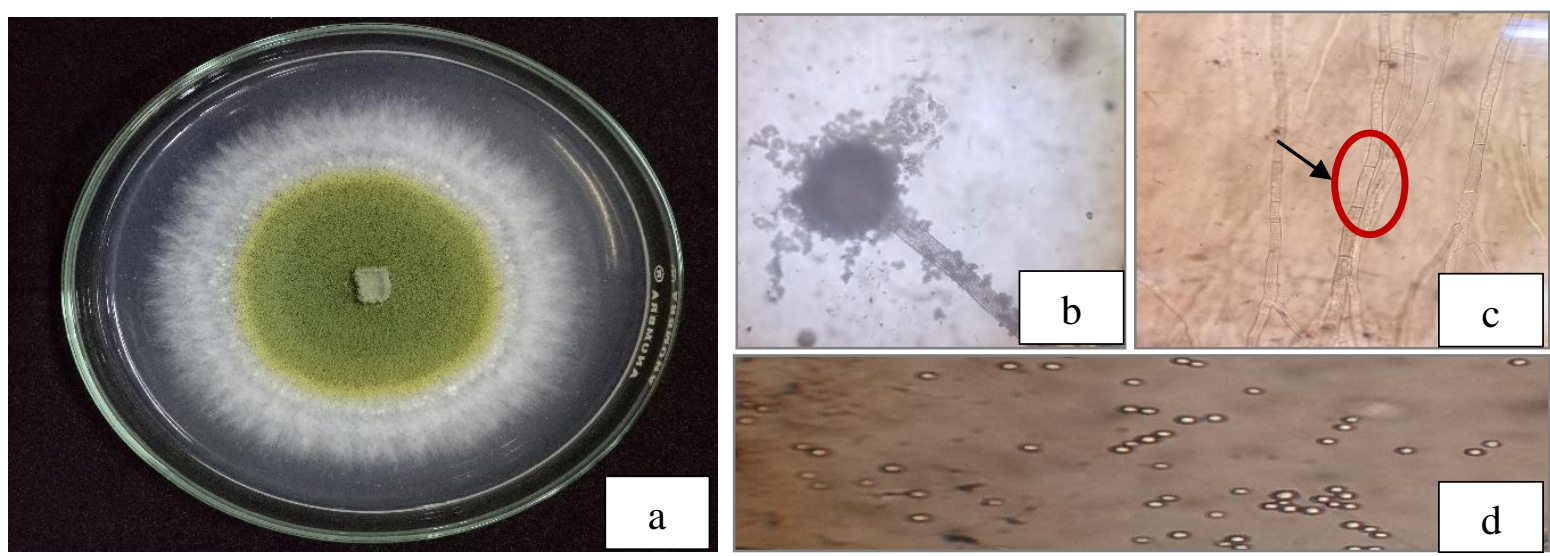

Fig. 1. Macroscopic (a) and microscopic of Aspergillus, conidiophore (b), hypha with setae (c), conidia (d)
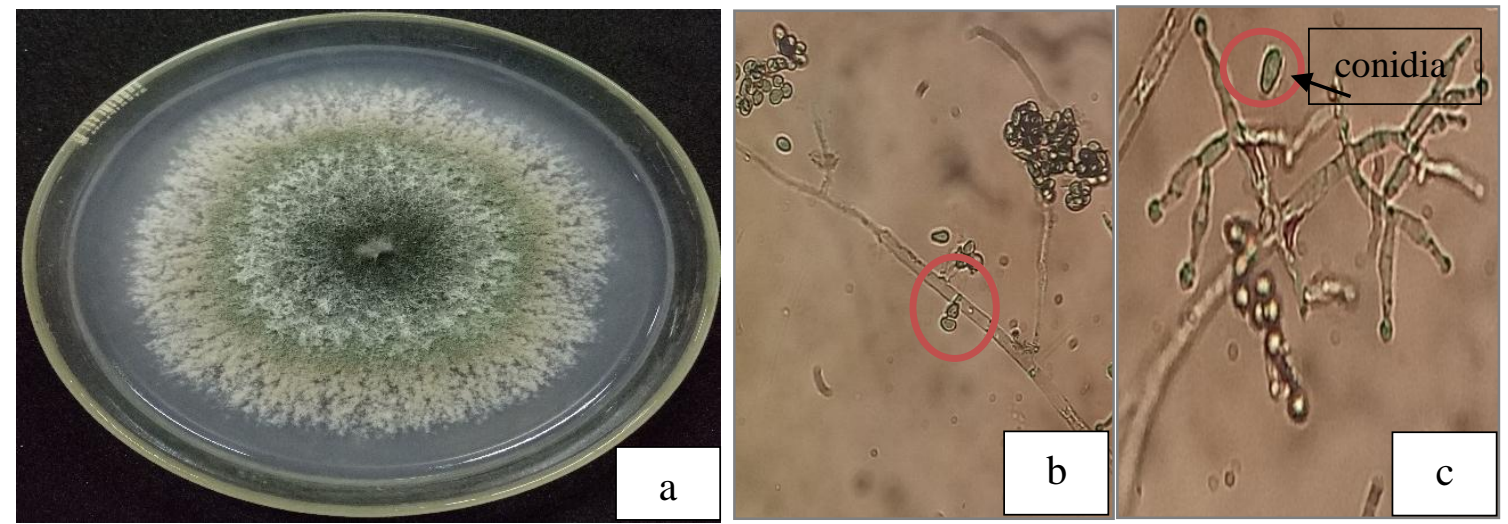

Fig. 2. Macroscopic (a) and microscopic of Trichoderma, hypha with setae (b), conidia and conidiophores (c) 

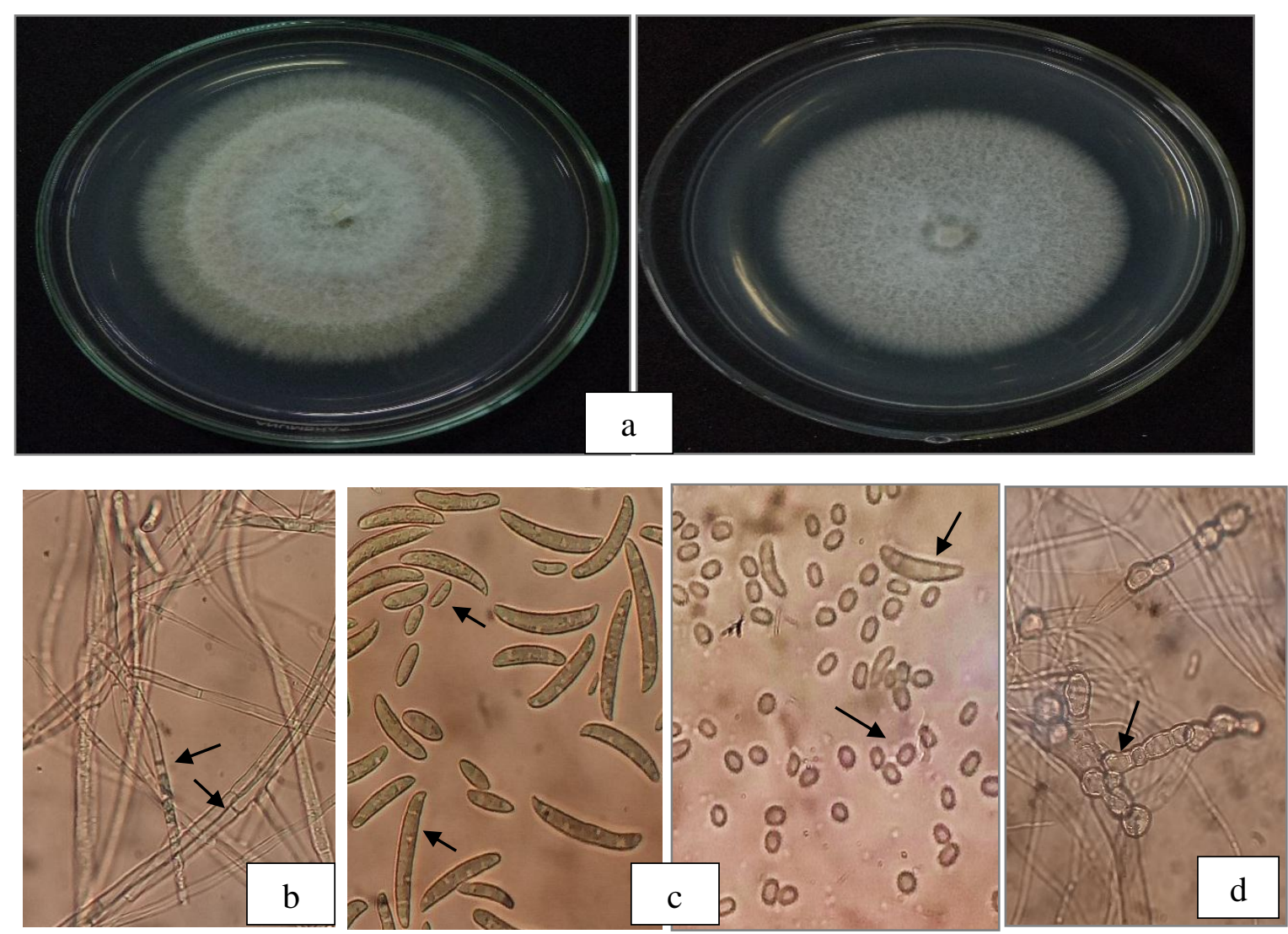

Fig. 3. Macroscopic (a) and microscopic of Fusarium, hypha with setae (b), microconidia and macroconidia (c), chlamydospores (d)
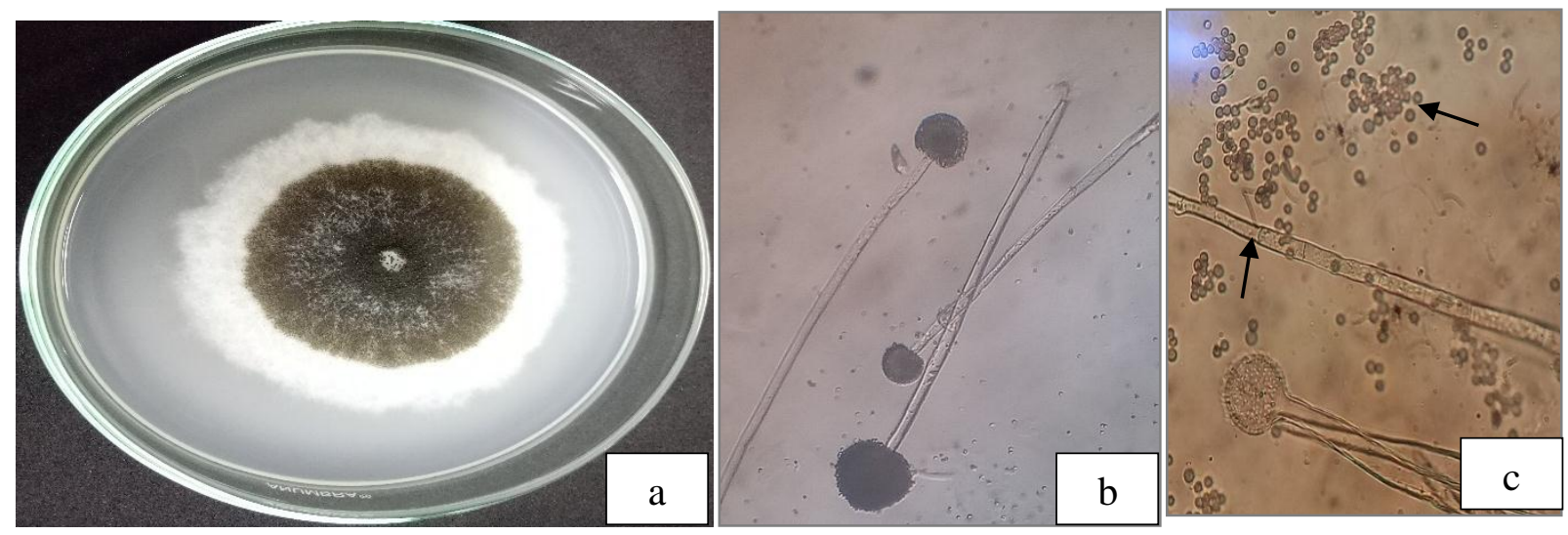

Fig. 4. Macroscopic (a) and microscopic of Aspergillus, conidiophores (b), conidia and hypha with setae (c).

\section{Bioassay Test of Enthomophatogenic Fungi}

Six isolates were isolated from semi-organic rhizosphere, there were three isolates of Fusarium sp, two isolates of
Aspergillus sp., one isolate of Trichoderma sp. Each of the fungi was found in application on test insects, the average mortality of test insects on (Table 3). 
Table 3. Mortality of T. molior Larvae Infected of Fungi on Semi-organic Rhizosphere

\begin{tabular}{ccc}
\hline Isolates & Genera & \% Mortality of Larvae \\
\hline RSOT1 & Aspergillus & 80 \\
RSOT2 & Aspergillus & 60 \\
RSOT3 (1) & Fusarium & 20 \\
RSOT3 (2) & Trichoderma* & 80 \\
RSOT4 (1) & Fusarium & 60 \\
RSOT4 (2) & Fusarium & 60 \\
\hline
\end{tabular}

Note: *) Test insects of dead larvae, but the mycelia did not exit through the insect host and the numbers in brackets on the isolates showed that the larvae to-

Table 3 showed that the percentage of larvae mortality were infected of enthomophatogenic fungi on semi-organic rhizosphere, the percentage mortality infected by genera of Aspergillus sp. range the percentage was around $60-80 \%$ isolates of RSOT1 and RSOT2, Fusarium sp. 20\%-
$60 \%$ isolates of RSOT3 (1), RSOT4 (1) and RSOT4 (2), Trichoderma sp. 80\% isolate of RSOT3 (2).

Two isolates isolated from inorganic rhizosphere were Aspergillus spp., the average mortality of test insects on (Table 4).

Table 4. Mortality of T. molitor Larvae Infected of Fungi on Inorganic Rhizosphere

\begin{tabular}{ccc}
\hline Isolates & Genera & $\begin{array}{c}\text { \% Mortality of } \\
\text { Larvae }\end{array}$ \\
\hline RIOT1 (1) & Aspergillus & 100 \\
RIOT1 (2) & Aspergillus & 60 \\
\hline
\end{tabular}

Table 4 showed that the percentage of isolate of RIOT1 (1) $100 \%$, while isolate of larvae mortality were infected of RIOT1 (2) percentage of larvae mortality enthomophatogenic fungi on inorganic around $60 \%$. Entomopathogenic fungi that rhizosphere, the percentage mortality were infected and application T.molitor infected by genera of Aspergillus spp. were larvae on (Figure 5). 

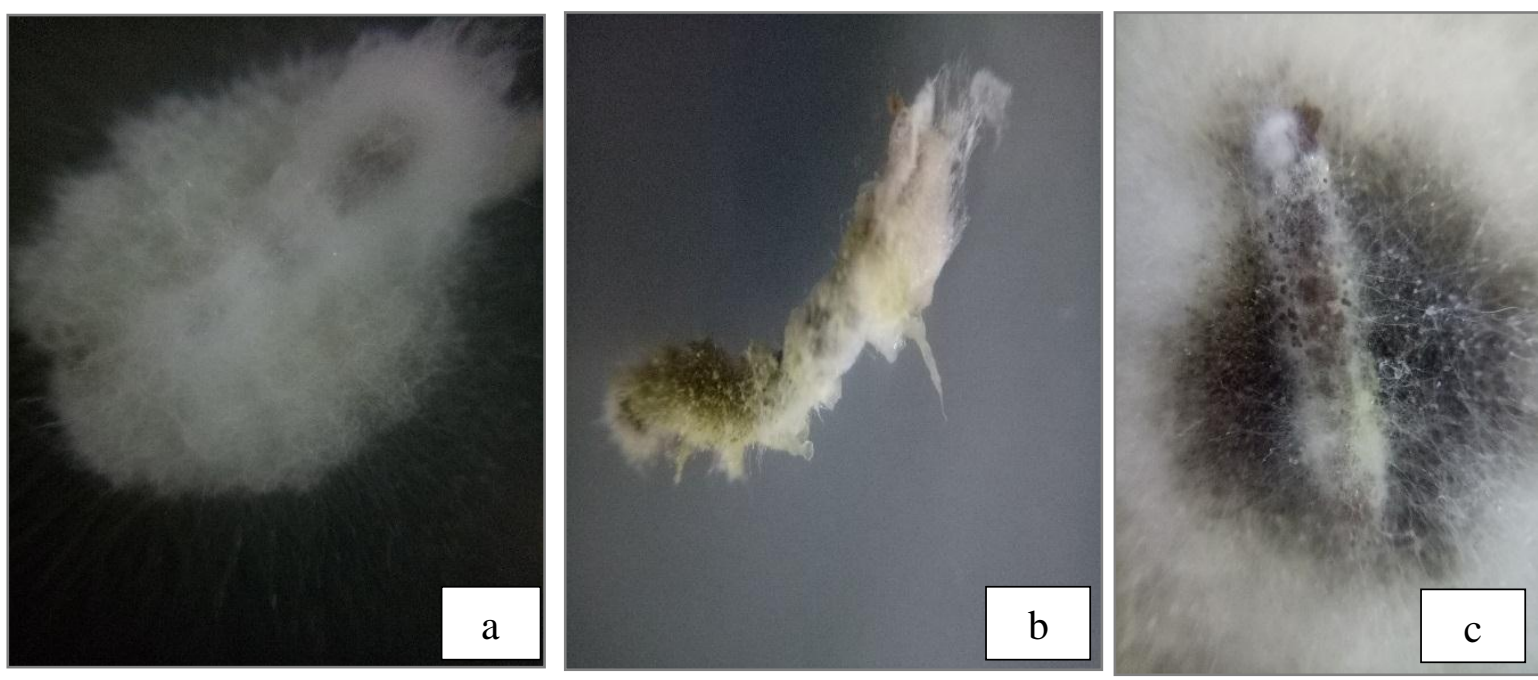

Fig. 5. Larvae T.molitor were infected of Fusarium sp. (a) and Aspergillus flavus (b) Aspergillus niger (RIOT1 isolate) (c)

The growth of fungi in culture media for 7 days isolated from semi-organic rhizosphere showed that as long as incubation period increase the growth of fungi colony diameter. This was occured in all type of fungi, which were isolates of
RSOT3(2) genera of Trichoderma sp. has rapid growth on PDA, followed by isolates of RSOT4 (1), RSOT4 (2), RSOT2, RSOT3 (1) and RSOT1 on (Figure 6) and from inorganic rhizosphere were isolates RIOT1 (1) and RIOT1 (2) on (Figure 7).

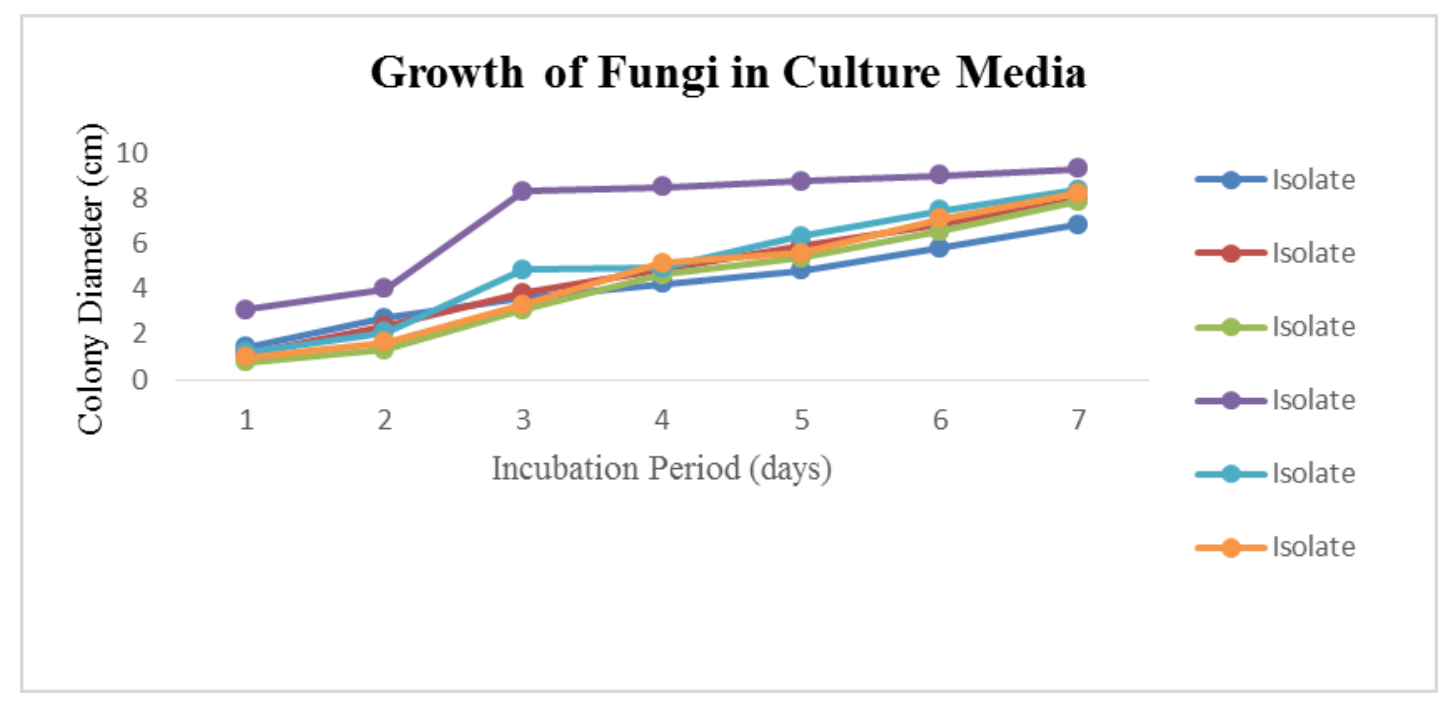

Fig. 6. The average growth of fungi in PDA media for 7 days on semiorganic rhizosphere 


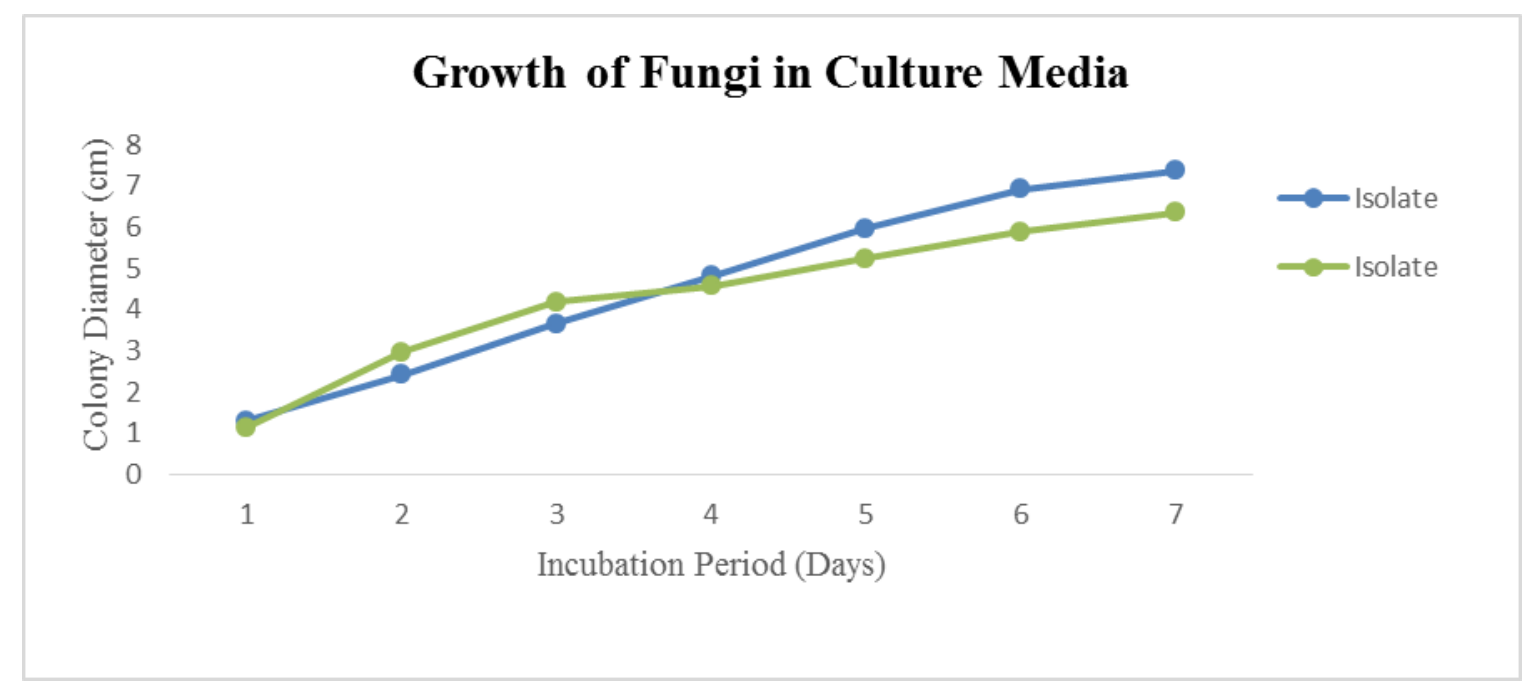

Fig. 7. The average growth of fungi in PDA media for 7 days on inorganic rhizosphere

Percentage of larvae mortality physically, chemically and in terms of soil infected by enthomophatogenic fungi were biology. Refer to Doeswono (1983), the different between semi-organic rhizosphere organic materials were a source of energy and inorganic rhizosphere. Semi-organic and food for microorganisms living in the rhizosphere were found 6 isolates from 3 soil. Soil microorganisms interact with genera of enthomophatogenic fungi while in organic material because their provide carbon inorganic rhizosphere were found 2 isolates as a source of energy to grow. The high from one genera. It caused of the conidial percentage of larvae mortality infected on density of each entomopathogenic fungus on semi-organic rice plants rhizosphere because semi-organic rhizosphere as well as favorable total of conidia and spores present in the environmental conditions. It was knew that rhizosphere. Tanada and Kaya (1993) on semi-organic rhizosphere were treated showed that the density of pathogens or with organic materials were used fertilizer, inoculum is one important factor of infection biological pesticides, prioritize using organic in insects. Soil microorganisms have an materials that organic materials were an important role in biogeochemical processes important ingredient for soil fertility, that determine the productivity of the plant as 
a microbial inoculant and affect on soil health. The dominant genera in all the agricultural crop fields were Aspergillus, Penicillium and Mucor (Chandrashekar et al., 2014).

On semi-organic and inorganic rhizosphere were found genera of Aspergillus spp. (Tables 1 and 2.), refer to Hidayat (2010) showed that enthomopathogenic fungi were isolated from agricultural fields genera of Aspergillus the most commonly were found. A. flavus subsists as mycelium, conidia, or sclerotia is one of the soil components associated with the soil organic materials (Hedayati, et al. 2007). Aspergillus spp. are able to assimilate minerals from minimal medium and survive on simple carbon and nitrogen sources with no vitamin requirements (Tarrand et al. 2005).

Previous studies have reported 11 isolates of fungi were found in two different locations on the chasew plants rhizosphere were Aspergillus flavus, A. niger, A. abdomen) covered all of host surface and parasiticus, Botrytis cinera, Cladosporium sphacospermum, Fusarium sporotrichioides, Penicillium brevicompactum, $P$. citrinum, $P$. chrysogenum, Rhizopus stolonifer and Synchephalastrum racemosum (Wulandari et al., 2011). Genera of fungi were isolated on the rhizosphere soil and rizoplan cassava plants cultivar TME 419 were Alternari, Aspergillus, Acremonium, Brettanomyces, Botrytis, Byssochlamys, Cladosporium, Doratomyces, Geotrichum, Humicola, Moniliella, Monascus, Neurospora, Oidiodendron, Penicillium, Pyricularia, Papulaspora, Rhodotorula, Rhizopus, Saccharomyces, Sporothrix, Trichothecium and Trichoderma (Sule and Oyeyiola, 2012). The larvae mortality by discoloration of the insect cuticle from light brown to dark brown and some subsequently were transformed into black color, characterized of conidia enthomophatogenic fungi penetrating the cuticle entry of insect host and absorbing insect host fluids. Then the mycelium exit through on host surface (e.g. the caput and growth on the host surface. Refer to Humber 
(2008) showed that the life cycle of CONCLUSIONS

entomopathogenic fungi against the insect

cuticle with spore germination and penetration, thereafter proliferation of cells in the fungus that eventually are causing the death of its host, death of the insects followed by the production of infective spores entry the host immediately to repeat it life cycle. The pathogenicity of fungal species was thought related to produce enzymes and mycotoxins during infection of the insect on contact with the cuticle and in hemosoel (Tanada and Kaya, 1993).

PDA has significant effect on the growth of fungal colony diameter, the growth of eight isolates on PDA are presented on (Figs. 6 and 7), PDA is a good medium for the culture of Fusarium, Aspergillus and Trichoderma, the growth of all isolates remained significantly high on this medium. PDA is one of the most commonly used culture media because of its simple formulation and its ability to support mycelial growth of a wide range of fungi (Sharma and Pandey, 2010).
Semi-organic rice plants rhizosphere were found six isolates genera of Fusarium sp., Trichoderma sp. and Aspergillus sp., while and on inorganic rice plants were found 2 isolates genera of Aspergillus spp. have a role as enthomophatogenic fungi.

\section{ACKNOWLEDGEMENT}

Authors would like to thank Ministry of Research, Technology and Higher Education for providing the financial.

\section{REFERENCES}

Assaf, L. H., Haleem, R. A., \& Abdullah, S. K. (2011). Association of Enthomophatogenic and Other Opportunistic Fungi with Insects in Dormant Locations. Jordan Journal of Biological Science, 4. 87-92.

Barnett, H. L., \& Hunter, B. B. (1972). Illustrated Genera of Imperfect Fungi. Mineapolis. United States of America: Burgess Publishing Company.

Bawin, T., Seye, F., Boukraa, S., Jean-Yves, Z., Fara, N .R., Quentin, Z., Mady N., Farnk D,. \& Frédéric F. (2016). Production of Two Enthomophatogenic Aspergillus species and insecticidal activity against the Mosquito Culex quinquefasciatus compared to Metharizium anisoplae. Journal of Biocontrol Science and Technology, 26: 617-629.

Chandrashekar, M. A., Pai, K. S., \& Raju, N. S. (2014). Fungal Diversity of 
Rhizosphere Soils in Different Agricultural fields of Nanjangud Taluk of Mysore Karnataka India. International Journal of Current Microbiology and Applied Science, 3 (5) : 559-566.

Goettel, M. S., Eilenberg, J,. \& Glare, T. R. (2010). Entomopathogenic Fungi and their Role in Regulation of Insect Populations. In Gilbert, L.I. \& Gill, S.S. (Eds.), Insect Control Biological and Synthetic Agents.( p.p. 387- 431).

Hamdani., Yaherwandi., \& Trizelia. (2011). Potensial of Indigenous Enthomophatogenic Fungi as Biological Control of Cocoa Pod Borer, Conopomorpha cramerella Snell (Lepidoptera: Gracillariidae). Journal of Manggaro. 12 (2): 75-80.

Hedayati, M.T., Pasqualotto, A.C., Warn, P.A., Bowyer, P., \& Denning, D.W. (2007). Aspergillus flavus: human pathogen, allergen and micotoxin producer. Journal of Microbiology. 153: $1677-1692$.

Herlinda, S. (2010). Spore Density and Viability of Enthomopathogenic Fungal Isolates from Indonesia and their Virulence against Aphis gossypii Glover (Homoptera: Aphididae). J. of Tropical Life Sci. Res. 21 (1):13-21.

Hidayat, Y. (2010). Isolation of Enthomopathogenic Fungi on infected insects on Agricultural Fields X Koto Tanah Datar Regency. J.of Saintek. 2(2) : 99-104.

Humber, R. A. (2008). Evolution of Entomopathogenicity in Fungi. J. of Invertebrate Pathology. 98: 262-266.

Kuswinanti, T., Baharuddin, \& Sukmawati S. (2014). Effectiveness of Bacterial Isolates from Several Rhizospheres and Organic Materials against Ralstonia solanacearum and Fusarium oxysporum on Potato. Journal of Phytopathology Indonesia. 10 (2): 6872.

Malekan, N., Hatami, B., Ebadi, R., Alireza, A., \& Rouhollah R. (2015). Evaluation of Enthomophatogenic fungi Beauveria bassiana and Lecanicillium muscarium on different nymphal stages of greenhouse whitefly Trialeurodes vaporariorum in greenhouse conditions. Journal of Biharean Biologist, 9 (2): 108-112.

Nurariaty, A., Saranga, P. A., Rosmana, A., \& Tambingsila, M. (2013). Potential of Rhizosphere Fungi as Biological Control Agent of Cocoa Plant Pests and Diseases. Proceedings of National Seminar and Congres of PFI XXI, Padang, 08-10 October 2013.

Priwiratama, H,. \& Susanto A. (2014). Utilization of Fungi for the Biological Control of Insect Pests and Ganoderma Disease in the Indonesia Oil Palm Industry. Journal of Agriculture Science and Technology. 4:103-111.

Sharma, G., \&Pandey, R.R. (2010). Influence of Cultural Media on Growth, Colony Character and Sporulation of Fungi isolated from Decaying Vegetables Wastes. J. of Yeast and Fungal Res. 1 (8) 157-164.

Sule, I. O., \& Oyeyiola, G.P. (2012). Fungi in the Rhizosphere and Rhizoplane of Cassava cultivar TME 419. International Journal of Applied Biological Research. $4(1,2)$ : 18 - 30.

Tanada, Y., \& Kaya, H.K. (1993). Insect Pathology. New York: Academic Press, Inc.

Tarrand, J. J., Han, X. Y., Kontoyiannis D. P., \& May G. S. (2005). Aspergillus hyphae in infected tissue: evidence of physiologic adaptation and effect on culture recovery. Journal of Clinical Microbiology 43 (1) 382-386.

Trizelia, Syahrawati M., \& Mardiah A. (2011). Pathogenicity Some Isolates of Enthomopathogenic fungi Metarhizium spp. against egg of Spodoptera litura Fabricius (Lepidoptera: Noctuidae). $J$. of Enthomology Indonesia. 8: (1) 4554.

Trizelia, Armon N., \& Jailani H. (2015). The Diversity of Entomopathogenic Fungi on Rhizosphere of Various Vegetable Crops. Proceedings of National 
Seminar of Biodiversity Society

Indonesia, August 2015. pp. 998-1004.

Watanabe, T.(2002). Pictorial Atlas of Soil and Seed Fungi. Morphologies of Cultured Fungi and Key to Species. (2nd Ed). CRC Press LCC. New York, Wahington, D.C.

Wulandari, N. L. D., Proborini, M. W., \& Sundra I.K. (2013). Eksploration of Soil Fungi Spatial on Cashew Plants Rhizosphere (Anacardium Occidentale L.) at Karangasem and Buleleng-Bali. Simbiosis J. of Biological Sci. 1 (2): 85-101.

Zimmermann, G. (1986).The Galleria Bait

Method for Detection of Entomopathogenic Fungi in Soil. Journal of Applied Entomology. 102:213-215. 